\title{
List otwarty Pedagogów - Członków Komitetu Nauk Pedagogicznych Polskiej Akademii Nauk
}

„Wzywam o Magna Charta Libertatis, o prawa dziecka” - taki apel ponad 100 lat temu wystosował do wszystkich dorosłych Janusz Korczak. Wołał o godność dziecka, o szacunek dla dziecka, o prawo do życia i godnej śmierci. Z takim korczakowskim przesłaniem Polska inicjowała Konwencję o prawach dziecka - międzynarodowy dokument zobowiązujący wszystkie państwa świata do ochrony praw i pomocy potrzebującym dzieciom.

O tę pomoc wołają dziś dzieci i ich matki na granicy polsko-białoruskiej. Wołają o prawo do życia, o niezbywalną godność małego uchodźcy koczującego w lesie, wypychanego, wyrzucanego, wywożonego z rodziną z kraju nazywanego ojczyzną praw dziecka.

Mamy wszyscy prawo i obowiązek strzec polskich granic, ale mamy także obowiązek chronić życie i pomóc każdemu dziecku w potrzebie. Na polsko-białoruskiej granicy rozgrywa się dramat humanitarny. Nie możemy być obojętni na los dzieci!

Rodzice, Dziadkowie, Wszyscy Ludzie Dobrej Woli - Lekarze, Prawnicy, Nauczyciele, Pracownicy Socjalni, Księża, Społecznicy i Wolontariusze, Artyści, Dziennikarze, Policjanci, Żołnierze, Strażnicy Graniczni, Parlamentarzyści, Członkowie Rządu - stańcie do obrony praw dzieci, stańcie do apelu przed Waszymi dziećmi, przed małymi uchodźcami, przed społeczeństwem, przed historią i Bogiem!

Stanowczo sprzeciwiamy się złej polityce władz wobec uchodźców, a zwłaszcza wobec dzieci i kobiet. Jako pedagodzy wiemy, że niehumanitarne działania władzy niszczą wrażliwość społeczną.

Prawda historyczna kiedyś jednoznacznie oceni postawę wobec cierpienia dzieci - uchodźców na granicy polsko-białoruskiej! Nie możemy pozostawać obojętni!

Sekcja Pedagogiki Społecznej Komitetu Nauk Pedagogicznych PAN przewodnicząca - prof. dr hab. Barbara Smolińska-Theiss Sekcja Edukacji Elementarnej Komitetu Nauk Pedagogicznych PAN przewodnicząca - prof. dr hab. Józefa Bałachowicz Międzynarodowe Stowarzyszenie im. Janusza Korczaka przewodniczący - dr Marek Michalak 
Sekcja Pedagogiki Kultury i Edukacji Międzykulturowej Komitetu Nauk Pedagogicznych PAN przewodniczący - prof. dr hab. Jerzy Nikitorowicz Sekcja Pedagogiki Resocjalizacyjnej Komitetu Nauk Pedagogicznych PAN przewodniczący - prof. dr hab. Wiesław Ambrozik prof. dr hab. Marek Konopczyński

Warszawa, 4 X 2021 r.

DOI: 10.14746/psn.2021.2.11 